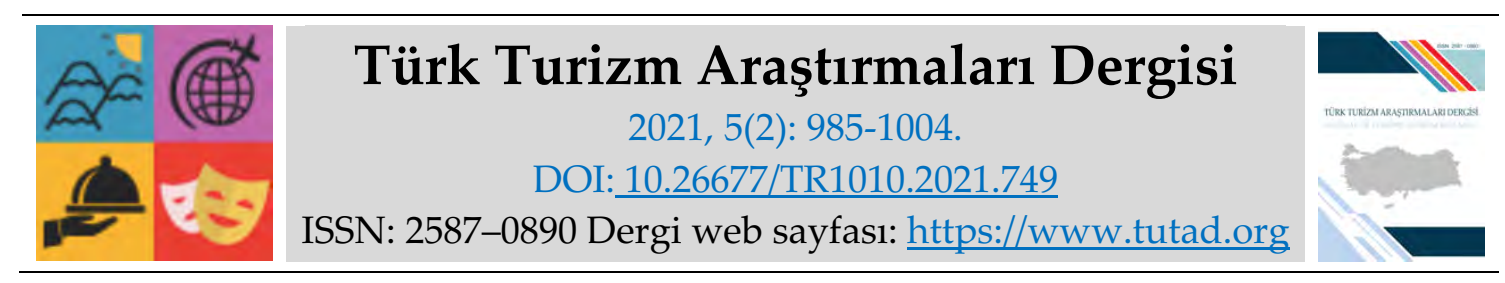

ARASTIRMA MAKALESI

\title{
Kent Sanal Turlarında Kültürel Mirasın Değerlendirilmesi
}

Doç. Dr. Hicran Hanım HALAÇ, Eskişehir Teknik Üniversitesi, Mimarlık ve Tasarım Fakültesi, Eskişehir, e-posta: hhhalac@eskisehir.edu.tr ORCID: https://orcid.org/0000-0001-8046-9914

Büşra SAATCİ İZCI, Doktora Öğrencisi, Eskişehir Teknik Üniversitesi, Mimarlık ve Tasarım Fakültesi, Eskişehir, e-posta: busrasaatci@eskisehir.edu.tr ORCID: https://orcid.org/0000-0003-2478-5597

Öz

Gelişen teknoloji ortamında bilgiye hızlı erişim önemlidir ve bu erişimi sağlayan araçlardan birisi sanal turlardır. Kentlerin tanıtılması için de kullanılan sanal turlar kentlere erişebilmek, algılayabilmek ve kentlerin kültür miraslarını tanımak açısından önemli bir araçtır. Çalışmanın amacı tanıtım amacıyla hazırlanan kent sanal turları ve bu sanal turlarda kültür miraslarına yer verme oranlarını tespit etmek ve değerlendirmektir. Çalışmada Yandex ve Google arama motorlarında sanal tur, kent sanal turu, $3 \mathrm{~d}$ gezi ve 360 tur anahtar kelimelerine il adları eklenerek arama yapılmış ve 26 ile ait 28 adet sanal tura ulaşılmıştır. Bulunan sanal turlardaki verilerin düzeni, müzik ve video gibi eklentiler ve sanal turda yer verilen kültür mirasının sayısı analiz edilmiştir. Çalışma sonucunda kent sanal turlarının genel olarak birbirinden farklı düzenlendiği, sanal turların herkes tarafından kullanılabilirliğini sağlayan ve bilgi veren eklentiler bakımından yetersiz olduğu ve kentlerin çok sayıda kültür mirası olmasına rağmen çok azına sanal turda yer verildiği görülmüştür ve geliştirilmesi için önerilerde bulunulmuştur.

Anahtar Kelimeler: Sanal Tur, Kent Sanal Turu, 3d Gezi, 360 Tur, Kültürel Miras.

Makale Gönderme Tarihi: 24.11.2020

Makale Kabul Tarihi: 02.06.2021

\section{Önerilen Atıf:}

Halaç, H. H. ve Saatci İzci, B. (2021). Kent Sanal Turlarında Kültürel Mirasın Değerlendirilmesi, Türk Turizm Araştırmaları Dergisi, 5(2): 985-1004.

(C) 2021 Türk Turizm Araştırmaları Dergisi. 


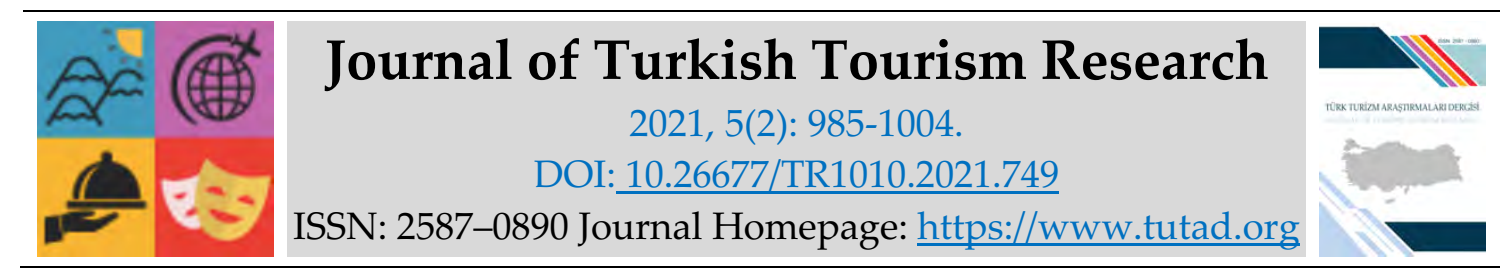

\title{
RESEARCH PAPER
}

\section{Evaluation of Cultural Heritage in City Virtual Tours}

Associate Prof. Dr. Hicran Hanım HALAÇ, Eskişehir Technical University, Faculty of Architecture and Design, Eskişehir, e-mail: hhhalac@eskisehir.edu.tr

ORCID: https://orcid.org/0000-0001-8046-9914

Büşra SAATCİ İZCI, PhD. Student, Eskişehir Technical University, Faculty of Architecture and Design, e-mail: busrasaatci@eskisehir.edu.tr

ORCID: https://orcid.org/0000-0003-2478-5597

\begin{abstract}
Developing technology, fast access is important and one of these access tools is virtual tours. Virtual tours used for the promotion of cities are not an important goal to reach, perceive and know the cultures of cities. The aim of the study is to identify and evaluate the promotion, virtual tours and the rate of including cultural heritage in these virtual tours. In the study, virtual tour, city virtual tour, $3 \mathrm{~d}$ trip and 360 tour keywords were added to Yandex and Google search engines, and 28 virtual tours belonging to 26 were reached. The tour layout in the virtual tour, add-ons such as music and video and the number of cultural heritages included in the virtual tour were analyzed. The study found that virtual tours of the city were generally organized differently from each other, the availability of virtual tours by everyone and informational add-ons were insufficient, and although the cities have many cultural heritages, very few of them were included in the virtual tour and made suggestions for suggestions.
\end{abstract}

Keywords: Virtual Tour, City Virtual Tour, 3d Travel, 360 Tour, Cultural Heritage.

Received: 24.11 .2020

Accepted: 02.06.2021

\section{Suggested Citation:}

Halaç, H. H. and Saatci İzci, B. (2021). Evaluation of Cultural Heritage in City Virtual Tours, Journal of Turkish Tourism Research, 5(2): 985-1004.

(C) 2021 Türk Turizm Araştırmaları Dergisi. 


\section{Gíriş}

Gelişen teknolojinin ürünlerinden olan sanal tur, belirli bir amaç doğrultusunda kullanıcılara bilgi, tanıtım ve hizmet sunmayı amaçlayan; içerisinde görüntü, hareketli tasarım, yazı ile desteklenmiş sanal gerçeklik ürünleridir (Derman, 2012). Bir yere ait görüntü verilerini sanal ortama aktararak onların en üst düzeyde işlevsel fonksiyon sunmalarını sağlayan, mevcut konumun sanal simülasyonunu sunan sanal tur uygulaması günümüzde tanitım amaciyla pek çok alanda kullanılmaktadır (Aksoy ve Baş, 2020: 2546). Bu alanlardan birisi de kentlerdir. Kentlerin tanıtımları artık sanal tur aracılığıyla yapılmaya başlanmakta böylelikle kentlere dair verilere kentlere gitmeden de ulaşılabilmektedir. Kentlerdeki önemli tanıtım materyalleri ise kültürel ve doğal miraslardır. Sanal tur kavramının günümüzde hızla yayılmasıyla birlikte merak duygusunu arttırmak için panoramik görüntülere dayalı destinasyonların turistlere sunulması daha fazla kişi çekerek tanıtımla birlikte gelir elde edilen de bir ortam da sunmuş olmaktadır (Arat ve Baltacıoğlu, 2016). Sanal turlar kentlere ait kültürel ve doğal miraslar hakkında bilgi edinilmesine ve bu yerlere seyahat edilmesine yönelik karar verme sürecine katkı sağlayan bir araç haline gelmektedir. Kentlerdeki destinasyonlar hakkındaki bilgiye erişimin daha hızlı ve kolay olması sanal turları kent tanıtımında önemli destek haline getirmektedir (Aksoy ve Baş, 2020: 2546).

Kent tanıtımının sağlanması amacıyla ülkemizdeki pek çok kentte belediye, valilik ve il özel idaresi gibi kamu kurumları ile bazı işletmeler tarafından kentlerin sanal turları oluşturulmuştur. $\mathrm{Bu}$ çalışmanın amacı sanal turları olan kentleri tespit etmek ve tespit edilen sanal turların genel özelliklerini, kentteki kültürel miraslara yer verme oranlarını tespit etmek ve değerlendirmektir. Çalışma kapsamı sanal tur, kent sanal turu, 3d tur ve 360 tur anahtar kelimelerine Türkiye'deki il adları eklenerek Yandex ve Google arama motorlarında ilk sayfada aranan, kent bütününde sanal turu olan Türkiye'deki iller ve bu illere ait sanal turlardır.

\section{LITERATÜR}

Sanal tur, gelişen teknoloji sonrasında çok geniş bir kullanım alanına sahip olmuştur. Her alanda kullanılma potansiyeline sahip olan sanal tura dair literatür incelemesinde bulunan sonuçlar doğrultusunda yapılan çalışmaların genel olarak eğitim ve turizm alanında yapılmış olan tez ve makalelerden oluştuğu görülmektedir. Sanal turun eğitim aracı olarak kullanılmasına yönelik yüksek lisans ve doktora tezlerinin (Özer, 2016; Altınbay, 2019; Daşdemir, 2019; G1liç, 2020; Tay, 2020) ve makalelerin (Koca ve Daşdemir, 2018; Sungur ve Bülbül, 2019) özellikle son iki yılda yapıldığ 1 görülmektedir. Turizm alanında ve turizmle doğrudan ilişkili olan müzelerde sanal turun kullanımına yönelikte yine tez (Toprak, 2019) ve makaleler (Arat ve Baltacıŏlu, 2016; Oruç, Yıldırım, İmamoğlu, Demiroğlu ve Mehmet Burak, 2017; Durmaz, Bulut ve Tankuş, 2018; Sürme ve Atılgan, 2019; Taşkıran ve Kızılırmak, 2019) bulunmaktadır.

Arat ve Baltacıŏ̆lu (2016) turizm pazarına yeni katılmış olan sanal gerçeklik kavramı üzerinde durarak bunun etkileri üzerine teorik bir araştırma yapmıştır. Araştırmada sanal gerçeklilik sistemlerinin turizmde uygulanması ve bunun getireceği avantajlar, sanal tur, sanal tur tarihçesi ve sanal tur çeşitleri hakkında literatüre yer verilmiş ve son aşamada ise anket uygulaması yapılmıştır. Sanal tur uygulamaların ülke tanıtım çalışmalarında kullanımın artmasının beklendiğinden yerel ve bölgesel turistik destinasyonları kendilerini tanıtmada bu sayede yer bulduğu ve sanal turlar ile turizm acentelerinin fark yaratarak başarılı olacağı sonucu ortaya konmuştur.

Oruç ve diğerleri (2017), sanal gerçeklik uygulamalarının ve araçlarının müzelerde nasıl ve ne derece kullanıldığının saptanması amacıyla 3D gezintiye olanak sağlayan ve ülkemizde en çok 
ziyaret edilen Ayasofya Müzesi ile Fransa'da bulunan ve dünya çapında en çok ziyaretçi edilen Louvre Müzesi'nin sanal tur uygulamaları kullanış açısından karşılaştırılmıştır. Çalışmada sanal tur ile gezilen mekanların merak duygusunu harekete geçirerek o destinasyonların ya da mekanların ziyaret edilmesini sağlayacağı sonucuna ulaşılmıştır.

Durmaz ve diğerleri (2018), sanal gerçeklikle ilgili yapılan dünyada farklı alanlardaki çalışmaları incelenmiş ve Samsun ilindeki beş yıldızlı otellerde sanal gerçekliğin turizme entegrasyonu sözlü derinlemesine mülakat tekniği ile tespit etmiştir. Sürekli gelişim içinde olan işletmelerin sanal teknolojiyi müşterilerine sunmasıyla birlikte, bu teknolojinin müşteri memnuniyeti oluşmasına katkı sağlayacağı ortaya konmuştur.

Sürme ve Atılgan (2019), sanal müzede sanal tur kullanan bireylerin memnuniyet düzeylerini anket çalışması üzerinden değerlendirmiş ve sanal ortamın kullanılabilirliği arttıkça sanal tur memnuniyetinin de arttığı sonucuna ulaşmıştır.

Taşkıran ve Kızılırmak (2019), müzeyi sanal ortamda 360 derece turla ziyaret eden müşterilerin, sanal deneyimlerinden yola çıkarak, sanal turun müşterilerin satın alma süreçlerindeki etkisinin ve gerçek deneyimi yaşama isteği ortaya çıkarıp çıarmadığı Panorama 1453 Tarih Müzesi örneği üzerinden odak grup görüşmesi yöntemiyle araştırmıştır. Çalışmada gerçek ziyaretin daha etkili olduğu, sanal deneyimin heyecan ve istek yaratacak güçte bir çekiciliği olmadığı sonucu elde edilmiş ve bunun geliştirilmesi için önerilerde bulunulmuştur.

Kültürel miras ve sanal tur ilişkisine dair Halaç ve Saatci (2018), Aksoy ve Baş (2020) ve Guliyeva ve Guliyev (2020)'in çalışmalarına ulaşılmıştır. Halaç ve Saatci (2018)'ye ait çalışmada kültürel miras olan tarihi yapılardaki kent müzeleri ve bu müzelerden sanal turu olanların tespiti yapılmış, sanal turu olan kent müzelerinden Bursa Kent Müzesi'nin ise yeni işlev sonrası mekanlardaki değişim ve dönüşümü sanal tur üzerinden analiz edilmiştir.

Aksoy ve Baş (2020)'ın çalışmasında dijital turizm, sanal tur, Teknoloji Kabul Modeli kavramları açıklanmış ve Türkiye'de şehir tanıtımında sanal tur kullanan 12 Büyükşehir Belediyesi verilen çalışmanın araştırma kısmında, bireylerin sanal tur kullanım niyetlerini etkileyen faktörlerin Teknoloji Kabul Modeliyle belirlenmesi ve elde edilecek analiz sonuçlarının ışığında birtakım öneriler sunulması amaçlanmıştır. Bu amaç doğrultusunda mobil internet kullanıcıları örneklemi üzerinden anket yöntemiyle veriler elde edilmiştir. Elde edilen veriler doğrultusunda dijital turizm çağında kent ve kentte yer alan destinasyonlar hakkında bilgi edinmede sanal tur kullanımının önemi ve gerekliliği ortaya konmuştur.

Guliyeva ve Guliyev (2020)'in çalışmasında savaşlar sonrası yok edilmiş ortak bellek anıtları için toplumların ürettiği alternatif anlatı biçimi olarak sanal rekonstrüksiyonun işlevselliği, Ermenistan - Azerbaycan Dağlık Karabağ savaşı sonrası yaşadığı topraklardan göçe mecbur kalan insanların terk ettikleri coğrafyadaki kültürel yapıtlar temel alınarak analiz edilmiştir. Sanal turların kültürel yapıtlarla bilgi edinme ve ortak kültür olan değerlerin kaybolmasının karşısını almada önemli işleve sahip olduğu sonucuna ulaşılmıştır.

Son yıllarda özellikle ağırlık verilen sanal tur uygulamasına dair literatürdeki çalışmalarda kentteki kültürel mirasın sanal tur aracıllğııla tanıtılmasına yönelik bir çalışmaya rastlanmamıştır. Mevcut kent sanal turları üzerinden kentin ve kentteki kültürel mirasın yine kentte ait sanal tur üzerinden tanıtılması amacıyla yapılan bu çalışmanın literatüre katkı sağlaması hedeflenmektedir. 


\section{YÖNTEM}

\section{Veri Toplama Yöntemi}

Türkiye'deki 81 il için il adı (Artvin vs.) sanal tur, il adı kent sanal turu, il adı 3d gezi ve il adı 360 tur anahtar kelimeleri ile Yandex ve Google arama motorlarında tarama yapılmış ve ilk sayfada yer alan turlara bakılmıştır. Kenti bir bütün olarak kavratması açısından kent geneline ait uydu haritası veya hava fotoğrafı içeren sanal turlar seçilmiştir. Bulunan kent sanal turların her birinin ana sayfası, eklentileri ve verilen kültürel mirasları analiz edilmiştir.

Tablo 1. Sanal Turların Genel Bilgileri

\begin{tabular}{|c|c|c|c|c|}
\hline & İl & \begin{tabular}{|c|}
$\begin{array}{c}\text { Kurum veya } \\
\text { İşletme }\end{array}$ \\
\end{tabular} & Erişim Adresi & $\begin{array}{l}\text { Erişim } \\
\text { Tarihi }\end{array}$ \\
\hline 1 & Afyonkarahisar & Belediye & http://www.afyon.bel.tr/modul/sanaltur/ & 16.04 .2020 \\
\hline 2 & Artvin & İşletme & $\begin{array}{l}\text { http://www.co2medya.com/kta/artvin/turistik/tur/artvi } \\
\text { n.html }\end{array}$ & 16.04 .2020 \\
\hline 3 & Balıkesir & Belediye & https://balikesir.bel.tr/360/index.html & 2.04 .2020 \\
\hline 4 & Bartın & İşletme & http://www.bartinsanaltur.com/ & 2.04 .2020 \\
\hline 5 & Batman & Belediye & http://2aajans.com/sanaltur/batman/ & 16.04 .2020 \\
\hline 6 & Bayburt & Belediye & http://www.bayburt.bel.tr/webfiles/360/index.html & 2.04 .2020 \\
\hline 7 & Çorum & Valilik & $\begin{array}{l}\text { http://corum.gov.tr/ortak_icerik/corum/sanaltur/index. } \\
\text { html }\end{array}$ & 2.04 .2020 \\
\hline 8 & Denizli & Belediye & https://www2.denizli.bel.tr/sanaltur/ & 2.04 .2020 \\
\hline 9 & Elazığ & Belediye & https://www.elazig.bel.tr/sanal360/ & 2.04 .2020 \\
\hline 10 & Gaziantep & Belediye & https://gaziantep.bel.tr/sanal/index.html & 2.04 .2020 \\
\hline 11 & Giresun & İşletme & $\begin{array}{l}\text { http://www.co2medya.com/kta/giresun/turistik/tur/gire } \\
\text { sun.html }\end{array}$ & 2.04 .2020 \\
\hline 12 & Gümüşhane & İşletme & $\begin{array}{l}\text { http://www.co2medya.com/kta/gumushane/turistik/tur } \\
\text { /gumushane.html }\end{array}$ & 17.04 .2020 \\
\hline 13 & Kahramanmaraş & \begin{tabular}{|l|} 
Belediye \\
\end{tabular} & http://kahramanmaras.bel.tr/3d-sanal-tur & 2.04 .2020 \\
\hline 14 & Karabük & Belediye & http://360.karabuk.bel.tr/ & 2.04 .2020 \\
\hline 15 & Kastamonu & Belediye & https://www.kastamonu.bel.tr/sanaltur/index.html & 2.04 .2020 \\
\hline 16 & Kayseri & Belediye & $\begin{array}{l}\text { https://cbs.kayseri.bel.tr/panoroma.html?p=360meydan } \\
\& v=04\end{array}$ & 2.04 .2020 \\
\hline 17 & Kirklareli & Valilik & $\begin{array}{l}\text { https://sanalgezinti.com/yeni/kirklareli- } \\
\text { valiligi/index.html }\end{array}$ & 2.04 .2020 \\
\hline 18 & Kırşehir & İşletme & http://www.co2medya.com/projeler/kirsehir/ & 2.04 .2020 \\
\hline 19 & Konya & Belediye & https://konya.bel.tr/360/ & 2.04 .2020 \\
\hline 20 & Mersin & Belediye & $\begin{array}{l}\text { https://vr.mersin.bel.tr/\#!/Ulu-Cami- } \\
\text { 31b/?dil=Tr\&ath=176\&atv=-39\&fov=82 }\end{array}$ & 2.04 .2020 \\
\hline 21 & Ordu & İşletme & http://www.co2medya.com/ordu/ & 2.04 .2020 \\
\hline 22 & Rize & İşletme & $\begin{array}{l}\text { http://www.co2medya.com/kta/rize/turistik/tur/rize.ht } \\
\mathrm{ml}\end{array}$ & 2.04 .2020 \\
\hline 23 & Samsun & \begin{tabular}{|l|l|} 
İl Özel \\
İdaresi
\end{tabular} & http://www.samsunsanaltur.com/ & 2.04 .2020 \\
\hline 24 & Şanlıurfa & Valilik & $\begin{array}{l}\text { http://www.sanliurfa.gov.tr/ortak_icerik/sanliurfa/kure } \\
\text { sel/index.html }\end{array}$ & 2.04 .2020 \\
\hline 25 & Tekirdağ 1.Sanal Tur & Belediye & http://www.panoraturk.com/360/tekirdag/index.htm & 2.04 .2020 \\
\hline 26 & Tekirdağ 2.Sanal Tur & İşletme & http://www.trakya360.com/ & 2.04 .2020 \\
\hline 27 & Trabzon 1.Sanal Tur & İşletme & http://www.trabzon360.com/ & 2.04 .2020 \\
\hline 28 & Trabzon 2.Sanal Tur & İşletme & $\begin{array}{l}\text { http://www.co2medya.com/kta/trabzon/turistik/tur/trab } \\
\text { zon.html }\end{array}$ & 2.04 .2020 \\
\hline
\end{tabular}

Çalışma kapsamında belirlenen kentlerdeki kültür mirasının tespiti ise Türkiye Kültür Portalı (https://www.kulturportali.gov.tr/) ve 2019 yılına ait UNESCO Dünya Mirası Türkiye Kalıcı ve Geçici Listelerinden (http://www.unesco.org.tr) yararlanılmışır. 
Çalışmada Google ve Yandex arama motorları kullanılmıştır. İki farklı arama motoru seçme nedeni aynı anahtar kelime ile tarandığında bir arama motorunda sanal tur bulunurken diğerinde bulunamamasıdır. Örneğin Yandex arama motorunda Afyon sanal tur, Afyon kent sanal turu, Afyon 3d gezi, Afyon 360 tur anahtar kelimeleri ile sonuç alınmazken Google arama motorunda bu anahtar kelimelerden sadece Afyon kent sanal tur anahtar kelimesi ile sonuç bulunamamış diğerlerinde sanal tura ulaşılmıştır. Yine aynı nedenle farklı anahtar kelimeler kullanılmıştır. Örneğin Google arama motorunda Artvin sanal tur ve Artvin 360 tur anahtar kelimeler tarandığında sanal tur bulunurken Artvin kent sanal turu ve Artvin 3d gezi anahtar kelimelerinde sonuç gelmemiştir. Bu yöntemle Türkiye'deki tüm illere bakılarak il ölçeğindeki sanal turlar toplanmıştır. Tablo 1'de sanal turu olan bu iller ve erişim adresleri verilmiştir. Bunlar; Afyonkarahisar, Artvin, Balıkesir, Bartın, Batman, Bayburt, Çorum, Denizli, Elazığ, Gaziantep, Giresun, Gümüşhane, Kahramanmaraş, Karabük, Kastamonu, Kayseri, Kırklareli, Kırşehir, Konya, Mersin, Ordu, Rize, Samsun, Şanlıurfa, Tekirdağ ve Trabzon'dur. Tekirdağ ve Trabzon'a ait farklı ikişer sanal tur mevcuttur. Buna göre toplam 26 il ve 28 kent sanal turuna erişilmiştir.

\section{Veri Analiz Yöntemi}

Sanal turlara erişim sağlayan anahtar kelimeler veriye ulaşılması bakımından değerlendirilmiştir. Arama motorları ve anahtar kelimelerden gelen sonuçların sayı ve oranları verilmiştir. Toplanan sanal turlar için ortak kriterler belirlenmiş ve bunlar üzerinden sanal turların değerlendirmeleri yapılmıştır. Bunlar değerlendirme ölçütleri başlı̆̆ı altında verilmiştir. Değerlendirme ölçütleri; ana sayfa analizi, sanal turu sağlayan kurum veya işletme ve sanal tur eklentileri olarak üç başlık altında toplanmıştır. Kültürel mirasın kent sanal turlarındaki yeri başlı̆̆ı altında kentlerin Kültür Portalında kayıtlı anıtsal kültür miraslarına ve UNESCO Dünya Mirası Türkiye Kalıcı ve Geçici Listesinde yer alan kültür miraslarına ne kadar yer verildiği sayısal olarak analiz edilmiştir.

\section{BULGULAR}

\section{Sanal Tur ile İlgili Arama Motorlarında Aranan Anahtar Kelimeler ve Sonuçları}

Türkiye'deki 81 il için il adı (Artvin vs.) sanal tur, il adı kent sanal turu, il adı 3d gezi ve il adı 360 tur anahtar kelimeleri ile Yandex ve Google arama motorlarında tarama yapılmış ve ilk sayfada yer alan turlara bakılmıştır. Tablo 2'de il adı ile aratıldığında gelen ilçe sanal turlarına da sonuç alınmasından dolayı yer verilmiştir.

Tablo 2. Arama Motorlarında İl ve/veya İlçe Bazında Sonuç Alınan Anahtar Kelimeler

\begin{tabular}{|c|c|c|c|c|c|c|c|c|}
\hline $\begin{array}{c}\text { Arama } \\
\text { Motoru }\end{array}$ & \multicolumn{4}{|c|}{ Yandex } & \multicolumn{4}{c|}{ Google } \\
\hline $\begin{array}{c}\text { İl Adı } \\
\text { +Anahtar } \\
\text { Kelime }\end{array}$ & $\begin{array}{c}\text { Sanal } \\
\text { Tur }\end{array}$ & $\begin{array}{c}\text { Kent } \\
\text { Sanal } \\
\text { Turu }\end{array}$ & $\begin{array}{c}\text { 3D } \\
\text { Gezi }\end{array}$ & 360 Tur & $\begin{array}{c}\text { Sanal } \\
\text { Tur }\end{array}$ & $\begin{array}{c}\text { Kent } \\
\text { Sanal } \\
\text { Turu }\end{array}$ & $\begin{array}{c}3 \mathrm{D} \\
\text { Gezi }\end{array}$ & 360 Tur \\
\hline Toplam & 34 & 35 & 29 & 33 & 38 & 34 & 39 & 40 \\
\hline$\%$ & 41,9753 & 43,2098 & 35,8024 & 40,7407 & 46,9135 & 41,9753 & 48,1481 & 49,3827 \\
\hline
\end{tabular}

Yandex arama motorunda il ad 1 + sanal tur ile 34 ilde $\% 41,97$ oranında, il ad $1+$ kent sanal turu ile 35 ilde $\% 43,20$ oranında, il ad $1+3 \mathrm{D}$ gezi ile 29 ilde $\% 35,80$ oranında ve il ad $1+360$ tur ile 33 ilde $\% 40,74$ oranında sanal tura ulaşılmıştır. Yandex arama motorunda en fazla il adı kent sanal turu 
anahtar kelimesinden en az ise il adı $+3 \mathrm{D}$ gezi anahtar kelimesinden sonuç alındığı görülmektedir (Bkz. Tablo 2).

Google arama motorunda il ad $1+$ sanal tur ile 38 ilde $\% 46,91$ oranında, il ad $1+$ kent sanal turu ile 34 ilde $\% 41,97$ oranında, il ad $1+3 \mathrm{D}$ gezi ile 39 ilde $\% 48,14$ oranında ve il ad $1+360$ tur ile 40 ilde $\% 49,38$ oranında sanal tura ulaşılmıştır. Google arama motorunda en fazla il adı +360 tur anahtar kelimesinden en az ise il ad $1+$ kent sanal turu anahtar kelimesinden sonuç alındığ 1 görülmektedir (Bkz. Tablo 2).

Tablo 3'de Tablo 2'dekinden farklı olarak arama motorlarında il bütününde uydu haritası ve/veya hava fotoğrafı ile verilen sanal turlara ulaşılan aranan anahtar kelime sonuçlarına yer verilmektedir.

Tablo 3. Arama Motorlarında İl Bazında Sonuç Alınan Anahtar Kelimeler

\begin{tabular}{|c|c|c|c|c|c|c|c|c|}
\hline $\begin{array}{c}\text { Arama } \\
\text { Motoru }\end{array}$ & \multicolumn{4}{|c|}{ Yandex } & \multicolumn{4}{c|}{ Google } \\
\hline $\begin{array}{c}\text { İ Ad1 } \\
\text { +Anahtar } \\
\text { Kelime }\end{array}$ & $\begin{array}{c}\text { Sanal } \\
\text { Tur }\end{array}$ & $\begin{array}{c}\text { Kent } \\
\text { Sanal } \\
\text { Turu }\end{array}$ & $\begin{array}{c}\text { 3D } \\
\text { Gezi }\end{array}$ & 360 Tur & $\begin{array}{c}\text { Sanal } \\
\text { Tur }\end{array}$ & $\begin{array}{c}\text { Kent } \\
\text { Sanal } \\
\text { Turu }\end{array}$ & $\begin{array}{c}\text { 3D } \\
\text { Gezi }\end{array}$ & $\begin{array}{c}360 \\
\text { Tur }\end{array}$ \\
\hline Toplam & 23 & 22 & 18 & 22 & 25 & 19 & 24 & 24 \\
\hline$\%$ & 88,4615 & 84,6153 & 69,2307 & 84,6153 & 96,1538 & 73,0769 & 92,3076 & 92,3076 \\
\hline
\end{tabular}

Yandex arama motorunda il + sanal tur ile 23 ilde \%88,46 oranında, il ad $1+$ kent sanal turu ile 22 ilde $\% 84,61$ oranında, il ad $1+3 \mathrm{D}$ gezi ile 18 ilde $\% 69,23$ oranında ve il ad $1+360$ tur ile 22 ilde $\% 84,61$ oranında sanal tura ulaşılmıştır. Yandex arama motorunda en fazla il adı + sanal tur anahtar kelimesinden en az ise il adı $+3 \mathrm{D}$ gezi anahtar kelimesinden sonuç alındığ görülmektedir (Bkz. Tablo 3).

Google arama motorunda il + sanal tur ile 25 ilde \% 96,15 oranında, il ad $1+$ kent sanal turu ile 19 ilde $\% 73,07$ oranında, il ad $1+3 \mathrm{D}$ gezi ile 24 ilde $\% 92,30$ oranında ve il ad $1+360$ tur ile 24 ilde $\% 92,30$ oranında sanal tura ulaşılmıştır. Google arama motorunda da Yandex arama motorunda olduğu gibi en fazla il adı + sanal tur anahtar kelimesinden en az ise il adı + kent sanal turu anahtar kelimesinden sonuç alındığı görülmektedir (Bkz. Tablo 3).

\section{Kent Sanal Turlarının Değerlendirme Ölçütleri}

Anahtar kelimelerle arama motorlarında tarama sonuçları doğrultusunda kenti bütün olarak kavramayı sağlayan uydu haritası ve/veya hava fotoğrafı olan 26 ilde toplam 28 kent sanal turuna ulaşılmıştır. Bu sanal turlar ana sayfa analizi, sanal turu sağlayan kurum veya kuruluş, uydu haritası, hava fotoğrafı, müzik, sesli veya yazılı bilgilendirme ve bakı noktası sayısına göre değerlendirilmiştir.

Tablo 4' de kent sanal turlarının ana sayfaları verilmiştir. Ana sayfalar bazı kriterlere göre değerlendirilmiştir. Bunlar; ana sayfa arka fonu, sanal tur komutları, yapan kuruma ait logo, kurum veya işletme adı, proje adı ya da sanal tur adresinden hangisi mevcutsa bunun sanal tur ekranında bulunma yeri ve bakı listesinin sanal tur ekranındaki konumudur. 
Tablo 4. Kent Sanal Turlarının Ana Sayfaları

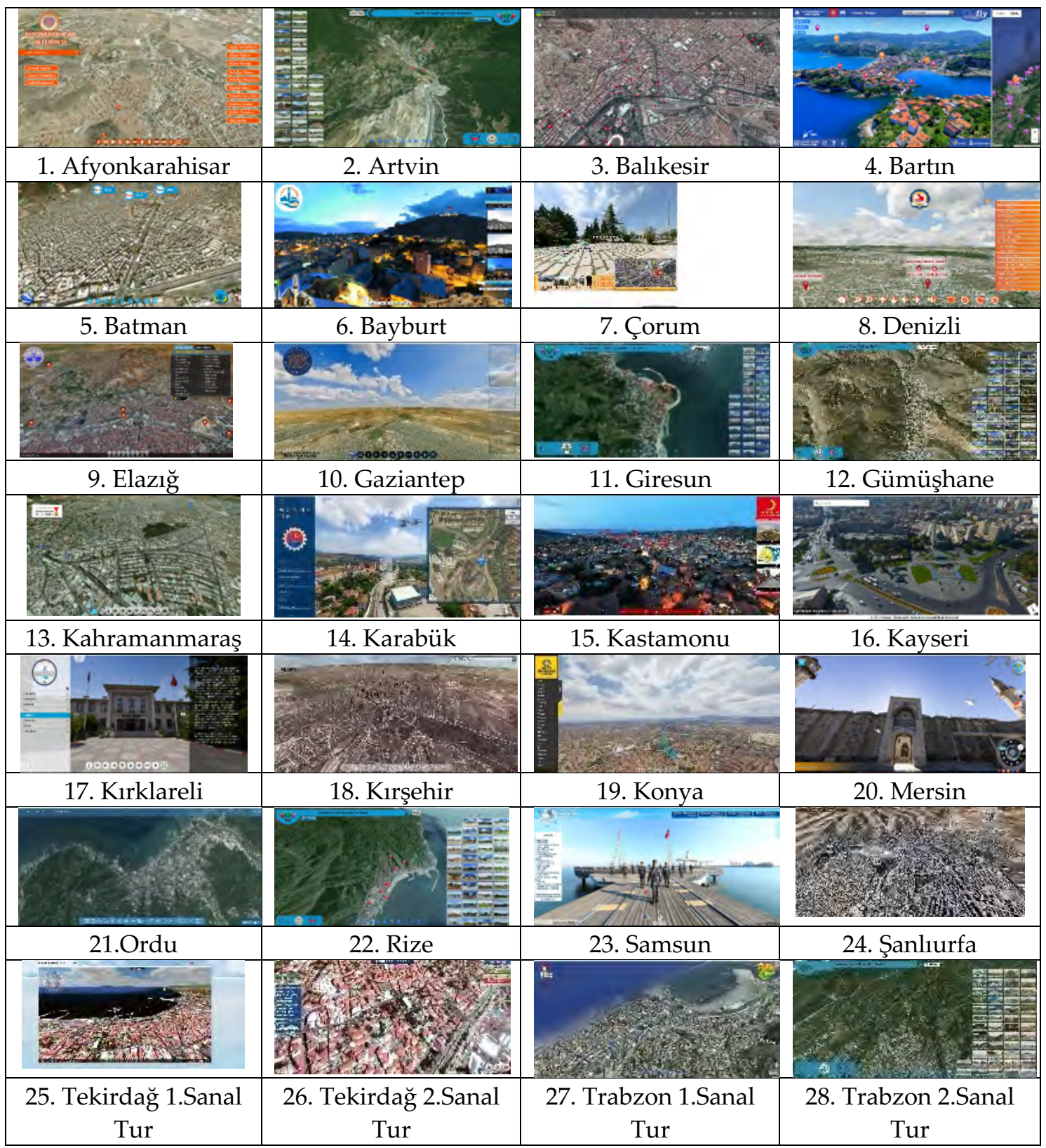

Sanal turların ana sayfalarında uydu haritasına, hava fotoğrafına, uydu ve hava fotoğrafına birlikte ya da yapı veya alana yer verilmiştir. Ana sayfalarında uydu haritasına yer veren sanal turlar 17 adetle $\% 60,71$ oranındadır. Hava fotoğrafını verenler beş adetle $\% 17,85$ oranındadır. Hem uydu haritası hem de hava fotoğrafını ana sayfa arka fonu olarak verenler iki adetle $\% 7,14$ oranındadır. Bunlar Bartın ve Karabük'tür. Bunlarda uydu haritası ve hava fotoğrafı eş zamanlı hareket etmektedir. Arka fonda yapı veya alana yer veren sanal turlar ise dört adetle \%14,28 oranındadır. Genel olarak sanal turlarda uydu haritasının arka fon olarak kullanıldığ görülmektedir (Bkz. Tablo 5). 
Tablo 5. Ana Sayfa Arka Fon Analizi

\begin{tabular}{|c|c|c|c|}
\hline & Örnekler & İller & Toplam \\
\hline 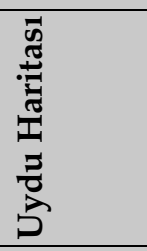 & $\frac{180}{\text { Balıkesir }}$ & $\begin{array}{c}\text { Artvin, Balıkesir, Batman, Denizli, } \\
\text { Elazığ,Gaziantep, Giresun, Gümüşhane, } \\
\text { Kahramanmaraş, Kırşehir, Ordu, Rize, Şanlıurfa, } \\
\text { Tekirdağ Sanal Tur 1, Tekirdağ Sanal Tur 2, } \\
\text { Trabzon Sanal Tur 1, Trabzon Sanal Tur 2 } \\
\end{array}$ & $\begin{array}{c}17 \\
(\% 60,71)\end{array}$ \\
\hline 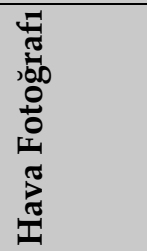 & $\frac{\text { (1) }}{\text { Bayburt }}$ & Afyon, Bayburt, Kastamonu, Kayseri, Konya & $\begin{array}{c}5 \\
(\% 17,85)\end{array}$ \\
\hline 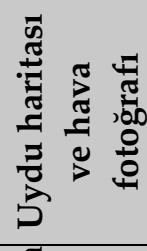 & 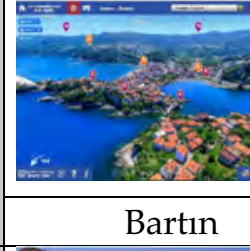 & Bartın, Karabük & $2(\% 7,14)$ \\
\hline 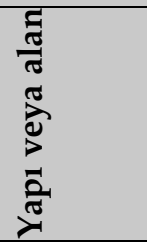 & $\frac{2.8}{\text { Mersin }}$ & Çorum, Kırklareli, Mersin, Samsun, & $\begin{array}{c}4 \\
(\% 14,28)\end{array}$ \\
\hline
\end{tabular}

Tüm sanal turlarda ileri, geri, durdur gibi sanal tur kontrolünü sağlayan komutlar ana sayfanın en altında ve genel olarak ortada yer almaktadır. Kayseri sanal turunda ise bu komut tuşları ise bulunmamaktadır.

Sol üst köşede genel olarak yapan kuruma ait logo, kurum veya işletme adı, proje adı ya da sanal tur adresi yer almaktadır. Sanal tur ekranın sol üst köşesinde yer alanlar 20 adetle \%71,42 oranındadır. Üst ortada yer alan bir adetle \%3,57 oranındadır. Sağ üst köşede yer alanlar üç adetle $\% 10,71$ oranındadır. Sağ alt köşede yer alan bir adetle \%3,57 oranındadır. Alt ortada yer alan bir adetle $\% 3,57$ oranındadır. Herhangi bir yazı veya logosu yer almayanlar ise iki adetle $\% 7,14$ oranındadır (Bkz. Tablo 6).

Sanal tur ekranında bakı noktalarının yer aldığı listeler vardır. Bunlar sanal tur ekranında bulundukları konuma göre ayrıştırılmıştır. Sağda yer alanlar 11 adetle $\% 39,28$, solda yer alanlar altı adetle \%21,42, hem solda hem sağda iki ayrı liste olarak yer alanlar üç adetle \%10,71, hem sağda hem ortada yer alan bir adetle $\% 3,57$, üstte yer alanlar dört adetle $\% 14,28$ altta yer alan bir adetle $\% 3,57$ ve listesi olmayanlar ise iki adetle \%7,14 oranındadır (Bkz. Tablo 7). 
Tablo 6. Logonun veya Kurum İşletme Adının Bulunduğu Konum Analizi

\begin{tabular}{|c|c|c|c|}
\hline & Örnekler & İller & Toplam \\
\hline $\begin{array}{l}\text { Sol üst } \\
\text { köşede }\end{array}$ & $\frac{0}{\substack{0.000090000 \\
\text { Gaziantep }}}$ & $\begin{array}{l}\text { Afyonkarahisar, Artvin, Balıkesir, Bartın, } \\
\text { Bayburt, Elazı̆̆, Gaziantep, Giresun, } \\
\text { Gümüşhane, Kahramanmaraş, Karabük, } \\
\text { Kırklareli, Kırşehir, Konya, Ordu, Rize, } \\
\text { Samsun, Tekirdağ Sanal Tur 1, Tekirdağ } \\
\text { Sanal Tur 2, Trabzon Sanal Tur } 2 \\
\end{array}$ & $\begin{array}{c}20 \\
(\% 71,42)\end{array}$ \\
\hline $\begin{array}{c}\text { Üst } \\
\text { ortada }\end{array}$ & Denizli & Denizli & $\begin{array}{c}1 \\
(\% 3,57)\end{array}$ \\
\hline $\begin{array}{l}\text { Sağ üst } \\
\text { köşede }\end{array}$ & 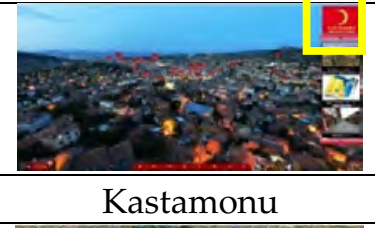 & Kastamonu, Mersin, Trabzon Sanal Tur 1 & $\begin{array}{c}3 \\
(\% 10,71)\end{array}$ \\
\hline $\begin{array}{l}\text { Sağ alt } \\
\text { köşede }\end{array}$ & 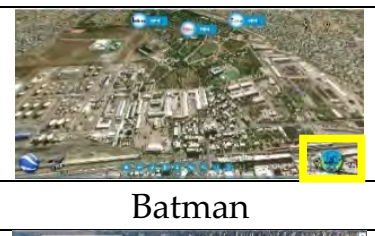 & Batman & $\begin{array}{c}1 \\
(\% 3,57)\end{array}$ \\
\hline Alt orta & ${ }_{\text {Kayseri }}$ & Kayseri & $\begin{array}{c}1 \\
(\% 3,57)\end{array}$ \\
\hline $\begin{array}{l}\text { Herhangi } \\
\text { bir yazi } \\
\text { veya } \\
\text { logo } \\
\text { olmayan }\end{array}$ & 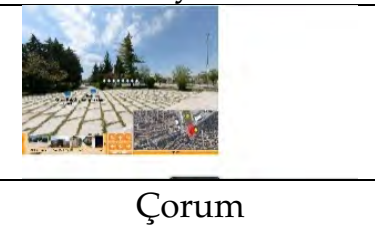 & Çorum, Şanlıurfa & $\begin{array}{c}2 \\
(\% 7,14)\end{array}$ \\
\hline
\end{tabular}


Tablo 7. Bakı Noktaları Listesinin Ekrandaki Konum Analizi

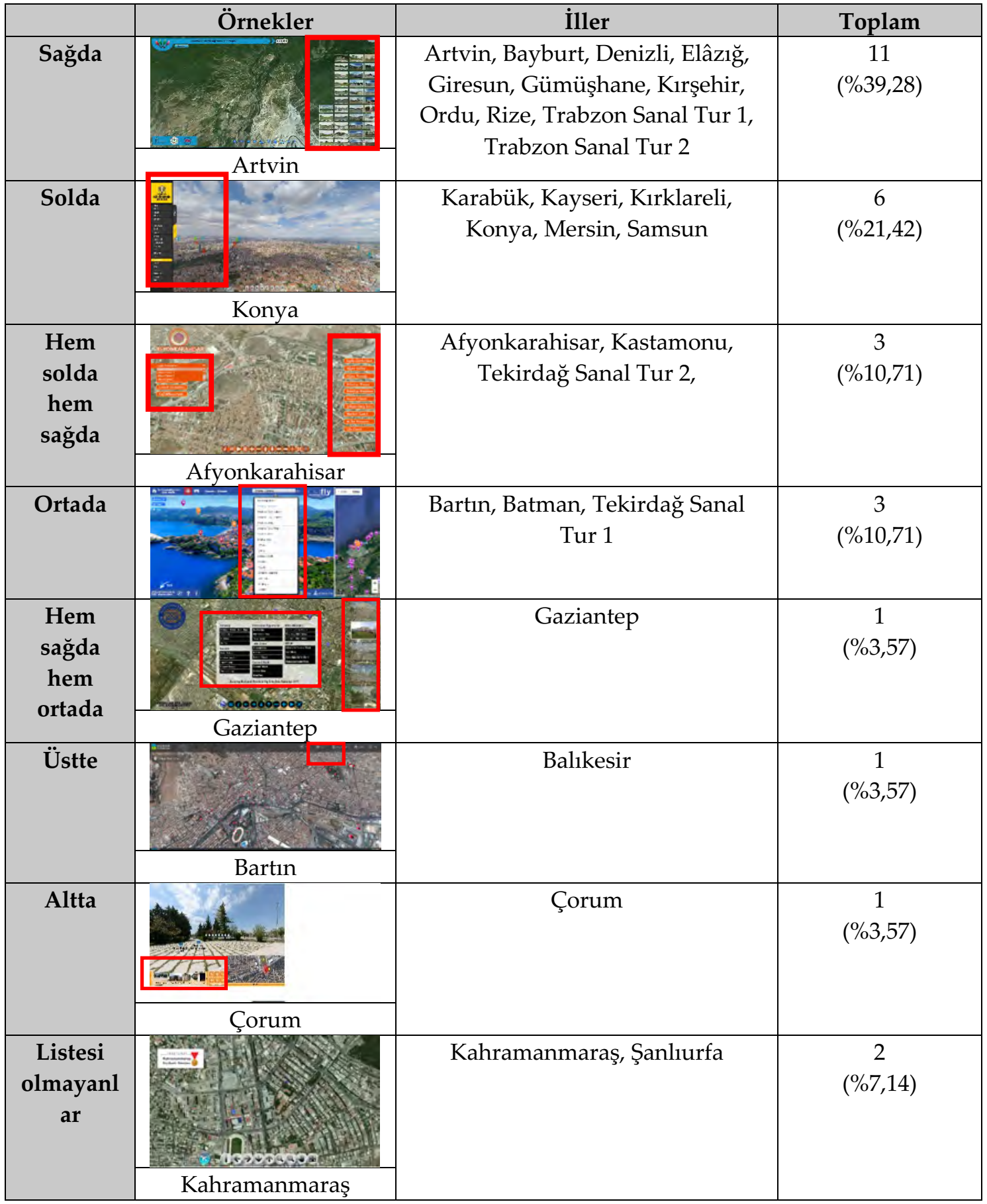

\section{Sanal Turu Sağlayan Kamu Kurum ve İşletme}

28 kent sanal turu 18 adetle $\% 64,28$ 'i kamu kurumları tarafından 10 adetle $\% 35,71^{\prime} i$ ise işletmeler tarafından erişimi sağlanmıştır (Bkz. Tablo 8). Kamu kurumları tarafından erişimi sağlanan sanal turların 14 adetle $\% 50$ 'si belediye, üç adetle $\% 10,71$ 'i valilik ve bir adetle $\% 3,57$ 'si il özel idaresi sayfalarında yer almaktadır. İşletmeler tarafından yapılanlar kategorisindeki sanal turların yedi adedi aynı işletme tarafından yapılmıştır. 
Tablo 8. Sanal Turu Sağlayan Kamu Kurum ve İşletme Sayı ve Oranı

\begin{tabular}{|c|c|c|c|c|}
\hline \multirow{2}{*}{$\begin{array}{c}\text { Sanal Turu } \\
\text { Sağlayan }\end{array}$} & \multicolumn{3}{|c|}{ Kamu Kurumu } & \multirow{2}{*}{ İşletme } \\
\cline { 2 - 4 } & Belediye & Valilik & İl Özel İdare & \\
\hline \multirow{2}{*}{ Toplam ve \% } & $14(\% 50)$ & $3(\% 10,71)$ & $1(\% 3,57)$ & \multirow{2}{*}{$10(\% 35,71)$} \\
\cline { 2 - 3 } & \multicolumn{3}{|c|}{$18(\% 64,28)$} & \\
\hline
\end{tabular}

\section{Sanal Tur Eklentileri}

Sanal turlarda kullanıma yönelik bazı eklentiler mevcuttur. İncelenen 28 adet kent sanal turlarında uydu haritası, hava fotoğrafı, video, müzik (yöreye özgü veya değil), bilgilendirme dil seçeneği (Türkçe, İngilizce vs.) ve bakı noktası eklentilerine rastlanmıştır. Tablo 9 ve Tablo $10^{\prime}$ da bu tespit edilen bu eklentilerden illere ait kent sanal turlarında hangilerine yer verildiği işaretlenerek tespit edilmiştir.

28 kent sanal turda uydu haritası 24 adetle \%85,71'inde bulunmaktadır. Hava fotoğrafı ise 10 adetle \%35,71'inde vardır. Barın, Bayburt, Elazığ, Karabük, Kastamonu, kayseri, Kırklareli, Konya, Mersin, Ordu kent sanal turlarında hava fotoğrafı mevcuttur. Bunların dışında kalan illerde uydu haritası vardır. Bartın, Elazı̆̆g, Karabük, Kastamonu, Mersin ve Ordu'da kent sanal turlarında ise uydu haritası ve hava fotoğrafı birlikte verilmektedir (Bkz. Tablo 9 ve Tablo 10).

Kent sanal turlarının iki adetle \%7,14'ünde video bulunmaktadır. Bu sanal turlar Bartın ve Batman kent sanal turlarındır (Bkz. Tablo 9 ve Tablo 10).

Müzik, kent sanal turlarının 11 adetle \%39,28'inde mevcuttur. Bunların altı adetle \%21,42'sinde fon müzik, üç adetle \%10,71'inde yöreye özgü fon müzik (Afyonkarahisar, Denizli, Şanlıurfa), bir adetle \%3,57'sinde ortam sesi (Ordu) ve bir adetle \%3,57 oranında yöresel müzik albümü (Kırklareli) yer almaktadır (Bkz. Tablo 9 ve Tablo 10).

Bilgilendirme kent sanal turların 10 adetle \%35,71'inde bulunmaktadır. Bunların yedi adetle $\% 25^{\prime}$, yazılı bilgilendirme ve üç adetle $\% 10,71$ 'i sesli bilgilendirmedir. Sesli bilgilendirmesi bulunan sanal turlar Kastamonu, Kırşehir ve Mersin kent sanal turlarıdır. Kastamonu kent sanal turunda sesli bilgilendirme sadece sanal tur tanıtımını içermektedir (Bkz. Tablo 9 ve Tablo 10).

Kent sanal turlarında dil seçeneği olanlar üç adetle \%10,71 oranındadır. Bunlar Balıkesir, Batman ve Mersin'dir. Balıkesir'de İngilizce, Batman'da İngilizce ve Kürtçe, Mersin'de İngilizce, Almanca ve Arapça dil seçeneği sunulmaktadır (Bkz. Tablo 9 ve Tablo 10).

Sanal turun içindeki tek noktadan sunulan panoramik görüntüyü ifade etmek için bakı noktası ifadesi kullanılmıştır. Uydu haritası bakı noktasında yer alan sanal turların bakı sayısından uydu haritası çıkarılarak değerlendirme yapılmıştır. Bakı nokta sayısına göre; 0-49 arasında bakı noktası olan sanal tur 13 adetle\%46,42 oranında, 50-99 arasında bakı noktası olan sanal tur dokuz adetle \%32,14 oranında, 100-149 arasında bakı noktası olan sanal tur üç adetle \%10,71 oranında, 300 ve üzeri arasında bakı noktası olan sanal tur üç adetle \%10,71 oranında ve 150-249 arasında bakı noktası olan sanal tur ise bulunmamaktadır (Bkz. Tablo 9, 10, 11). 
Tablo 9. Kentlerin Sanal Tur Eklentileri

\begin{tabular}{|c|c|c|c|c|c|c|c|c|c|c|c|c|}
\hline \multirow[b]{3}{*}{$\stackrel{0}{Z}$} & \multirow[b]{3}{*}{ ìl } & \multicolumn{11}{|c|}{ Sanal Tur Eklentileri } \\
\hline & & \multirow[b]{2}{*}{ 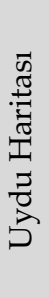 } & \multirow[b]{2}{*}{ 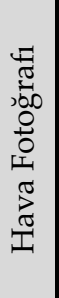 } & \multirow[b]{2}{*}{$\frac{8}{D_{0}^{\prime}}$} & \multirow[b]{2}{*}{ 冚 } & \multirow[b]{2}{*}{ 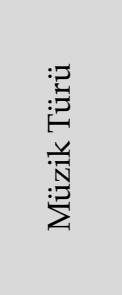 } & \multirow[b]{2}{*}{ 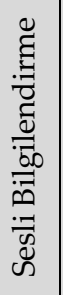 } & \multirow[b]{2}{*}{ 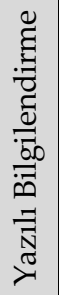 } & \multirow[b]{2}{*}{ 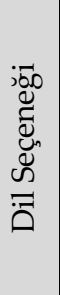 } & \multicolumn{3}{|c|}{ Bakı Noktası } \\
\hline & & & & & & & & & & 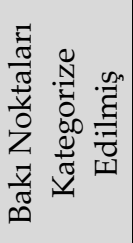 & 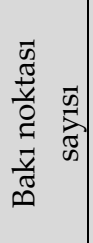 & 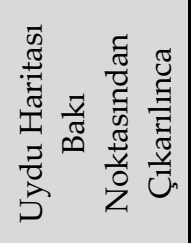 \\
\hline 1 & Afyonkarahisar & 1 & 0 & 0 & 1 & $\begin{array}{l}\text { Yöreye } \\
\text { Özgü }\end{array}$ & 0 & 1 & 0 & 1 & 41 & 40 \\
\hline 2 & Artvin & 1 & 0 & 0 & 1 & & 0 & 0 & 0 & 0 & 38 & 37 \\
\hline 3 & Balıkesir & 1 & 0 & 0 & 0 & & 0 & 0 & 1 & 1 & 284 & 284 \\
\hline 4 & Bartın & 1 & 1 & 1 & 0 & & 0 & 1 & 0 & 0 & 54 & 54 \\
\hline 5 & Batman & 1 & 0 & 1 & 0 & & 0 & 0 & 1 & 1 & 63 & 63 \\
\hline 6 & Bayburt & 0 & 1 & 0 & 0 & & 0 & 0 & 0 & 0 & 55 & 55 \\
\hline 7 & Çorum & 1 & 0 & 0 & 0 & & 0 & 0 & 0 & 0 & 13 & 13 \\
\hline 8 & Denizli & 1 & 0 & 0 & 1 & $\begin{array}{l}\text { Yöreye } \\
\text { Özgü }\end{array}$ & 0 & 1 & 0 & 0 & 32 & 32 \\
\hline 9 & Elazığ & 1 & 1 & 0 & 0 & & 0 & 0 & 0 & 0 & 50 & 50 \\
\hline 10 & Gaziantep & 1 & 0 & 0 & 0 & & 0 & 1 & 0 & 1 & 25 & 25 \\
\hline 11 & Giresun & 1 & 0 & 0 & 1 & & 0 & 0 & 0 & 0 & 36 & 35 \\
\hline 12 & Gümüşhane & 1 & 0 & 0 & 1 & & 0 & 0 & 0 & 0 & 44 & 43 \\
\hline 13 & Kahramanmaraş & 1 & 0 & 0 & 0 & & 0 & 1 & 0 & 0 & 27 & 27 \\
\hline 14 & Karabük & 1 & 1 & 0 & 0 & & 0 & 0 & 0 & 1 & 53 & 53 \\
\hline 15 & Kastamonu & 1 & 1 & 0 & 0 & & 1 & 0 & 0 & 0 & 114 & 113 \\
\hline 16 & Kayseri & 0 & 1 & 0 & 0 & & 0 & 0 & 0 & 0 & 19 & 19 \\
\hline 17 & Kırklareli & 0 & 1 & 0 & 1 & $\begin{array}{l}\text { Yöreye } \\
\text { Özgü }\end{array}$ & 0 & 1 & 0 & 1 & 67 & 67 \\
\hline 18 & Kırşehir & 1 & 0 & 0 & 1 & & 1 & 0 & 0 & 1 & 111 & 111 \\
\hline 19 & Konya & 0 & 1 & 0 & 0 & & 0 & 0 & 0 & 0 & 74 & 74 \\
\hline 20 & Mersin & 1 & 1 & 0 & 0 & & 1 & 0 & 1 & 1 & 374 & 374 \\
\hline 21 & Ordu & 1 & 1 & 0 & 1 & $\begin{array}{l}\text { Ortam } \\
\text { Sesi }\end{array}$ & 0 & 0 & 0 & 0 & 12 & 11 \\
\hline 22 & Rize & 1 & 0 & 0 & 1 & & 0 & 0 & 0 & 0 & 47 & 46 \\
\hline 23 & Samsun & 1 & 0 & 0 & 0 & & 0 & 0 & 0 & 0 & 543 & 543 \\
\hline 24 & Şanlıurfa & 1 & 0 & 0 & 1 & $\begin{array}{l}\text { Yöreye } \\
\text { Özgü }\end{array}$ & 0 & 0 & 0 & 1 & 82 & 82 \\
\hline 25 & $\begin{array}{c}\text { Tekirdağ 1.Sanal } \\
\text { Tur } \\
\end{array}$ & 1 & 0 & 0 & 0 & & 0 & 0 & 0 & 0 & 31 & 30 \\
\hline 26 & $\begin{array}{c}\text { Tekirdağ 2.Sanal } \\
\text { Tur } \\
\end{array}$ & 1 & 0 & 0 & 0 & & 0 & 1 & 0 & 0 & 105 & 105 \\
\hline 27 & $\begin{array}{c}\text { Trabzon 1.Sanal } \\
\text { Tur } \\
\end{array}$ & 1 & 0 & 0 & 0 & & 0 & 0 & 0 & 0 & 74 & 73 \\
\hline 28 & $\begin{array}{c}\text { Trabzon 2.Sanal } \\
\text { Tur } \\
\end{array}$ & 1 & 0 & 0 & 1 & & 0 & 0 & 0 & 0 & 50 & 49 \\
\hline
\end{tabular}


Tablo 10. Sanal Turdaki Eklentilerin Sayı ve Oranı

\begin{tabular}{|c|c|c|c|c|c|c|c|c|c|c|}
\hline & \multirow{3}{*}{ 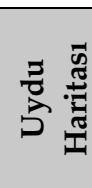 } & \multirow{3}{*}{ 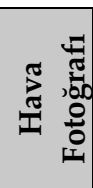 } & \multirow{3}{*}{$\frac{8}{8}$} & \multicolumn{4}{|c|}{ Müzik } & \multirow{2}{*}{\multicolumn{2}{|c|}{ Bilgilendirme }} & \multirow{3}{*}{ 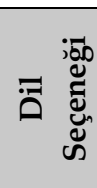 } \\
\hline & & & & \multicolumn{3}{|c|}{ Fon } & \multirow{2}{*}{$\begin{array}{l}\text { Yöresel } \\
\text { Müzik } \\
\text { Albüm }\end{array}$} & & & \\
\hline & & & & Fon & $\begin{array}{l}\text { Yöreye } \\
\text { Özgü }\end{array}$ & $\begin{array}{c}\text { Ortam } \\
\text { Sesi }\end{array}$ & & Yazilı & Sesli & \\
\hline \multirow{3}{*}{$\begin{array}{l}\text { Toplam } \\
\text { ve } \%\end{array}$} & \multirow{3}{*}{$\begin{array}{c}24 \\
\% 85 \\
71\end{array}$} & \multirow{3}{*}{$\begin{array}{c}10 \\
\% 35 \\
71\end{array}$} & \multirow[t]{3}{*}{$2 \% 7,14$} & 6 & 3 & 1 & 1 & 7 & 3 & \multirow{3}{*}{$\begin{array}{c}3 \\
\% 10,7 \\
1\end{array}$} \\
\hline & & & & $\% 21,42$ & $\% 10,71$ & $\% 3,57$ & $\% 3,57$ & $\% 25$ & $\% 10,71$ & \\
\hline & & & & \multicolumn{4}{|c|}{$11 \% 39,28$} & \multicolumn{2}{|c|}{$10 \% 35,71$} & \\
\hline
\end{tabular}

Tablo 11. Kent Sanal Turlarındaki Bakı Sayısı

\begin{tabular}{|c|c|c|c|c|c|c|c|}
\hline $\begin{array}{c}\text { Bak1 } \\
\text { Sayı1 }\end{array}$ & $\mathbf{0 - 4 9}$ & $\mathbf{5 0 - 9 9}$ & $\mathbf{1 0 0 - 1 4 9}$ & $\mathbf{1 5 0 - 1 9 9}$ & $\mathbf{2 0 0 - 2 4 9}$ & $\mathbf{2 5 0 - 2 9 9}$ & $\begin{array}{c}300 \text { ve } \\
\text { üzeri }\end{array}$ \\
\hline $\begin{array}{c}\text { Toplam } \\
\text { ve } \%\end{array}$ & $\begin{array}{c}13 \\
(\% 46,42)\end{array}$ & $\begin{array}{c}9 \\
(\% 32,14)\end{array}$ & $\begin{array}{c}3 \\
(\% 10,71)\end{array}$ & 0 & 0 & $\begin{array}{c}1 \\
(\% 3,57)\end{array}$ & $\begin{array}{c}2 \\
(\% 7,14)\end{array}$ \\
\hline
\end{tabular}

Bazı sanal turlarda bakı noktaları gösterilen yerin, yapının, alanın veya mekanın özelliklerine göre kategorize edilmiştir. 28 kent sanal turunun \%32,14'lük oranla dokuzunda bakı noktaları kategorize edilmiştir. Bunlar Afyonkarahisar, Balıkesir, Batman, Gaziantep, Karabük, Kırklareli, Kırşehir, Mersin ve Şanlıurfa kent sanal turlarıdır (Bkz. Tablo 9, Tablo 11).

\section{Kentlerdeki Kültür Mirasların Sanal Turdaki Analizi}

Kentler için kültür mirasları önemli bir tanıtım ve turizm kaynağı olmaktadır. Kentlerin bu mirasların tanıtımına, korunmasına ve geleceğe doğru aktarılmasına önem vermesi gerekmektedir. Gelişen teknoloji ve yaşam tarzıyla birlikte bu miraslara internet ortamında erişim sağlanması önem kazanmaktadır. Bu doğrultuda çalışmamızda kentlerdeki kültür mirasının tespiti ve bunların sanal turda yer verilme durumunu değerlendirmek amacıyla Türkiye Kültür Portalı (https://www.kulturportali.gov.tr/) ve 2019 yılına ait UNESCO Dünya Mirası Türkiye Kalıcı ve Geçici Listeleri (http://www.unesco.org.tr) kaynak olarak kullanılmıştır. Kentlere ait pek çok kültür mirası mevcuttur. Bu nedenle kapsam daraltılmasına gidilerek Türkiye Kültür Portalında il bazında sadece kayıtlı anıtsal kültürel miraslara bakılmıştır. UNESCO listesinde ise Türkiye' de yer alan kültürel miras ve karma miras alanlarına bakılmıştır.

Sanal turu olan 26 ilin 16 adetle \%61,53'ünün Türkiye Kültür Portalında kayıtlı anıtsal kültür mirası bulunmakta 10 adetle \%38,46' sında ise kayıtlı anıtsal kültür mirası bulunmamaktadır (Bkz. Tablo 12).

Sanal turu olan 26 ilden 5 adetle \%19,23'ünde UNESCO Dünya Mirası Kalıcı Listesinde kayıtlı miras varken 21 adetle \%80,76'sında kayıtlı miras yoktur. UNESCO Dünya Mirası Geçici Listesinde ise sanal turu olan 26 ilden 13 adetle $\% 50$ oranla yarısında kayıtlı miras varken 13 adetle $\% 50$ oranla diğer yarısında kayıtlı miras yoktur (Bkz. Tablo 12). 
Tablo 12. Sanal Turu Olan İllerdeki Kültürel Mirasların Başvurulan Kaynaklarda Kayıtlı Olma Durumu

\begin{tabular}{|c|c|c|c|c|c|c|}
\hline & \multicolumn{2}{|c|}{$\begin{array}{c}\text { Türkiye Kültür } \\
\text { Portalında Anıtsal } \\
\text { Kültürel Miras } \\
\end{array}$} & \multicolumn{4}{|c|}{$\begin{array}{l}\text { UNESCO Dünya Mirası Türkiye Kalıcı ve Geçici } \\
\text { Listesindeki Kültür Mirası }\end{array}$} \\
\hline & \multirow[b]{2}{*}{$\begin{array}{c}\text { Kültür } \\
\text { Portalında } \\
\text { Kayıtlı } \\
\text { Kültür } \\
\text { Mirası } \\
\text { Olanlar }\end{array}$} & \multirow[b]{2}{*}{$\begin{array}{c}\text { Kültür } \\
\text { Portalında } \\
\text { Kayıtlı } \\
\text { Kültür } \\
\text { Mirası } \\
\text { Olmayanlar }\end{array}$} & \multicolumn{2}{|c|}{ Kalıc Liste } & \multicolumn{2}{|c|}{ Geçici Liste } \\
\hline & & & $\begin{array}{c}\text { Kalıcı } \\
\text { Listede } \\
\text { Kültür } \\
\text { Mirası } \\
\text { Olanlar }\end{array}$ & $\begin{array}{c}\text { Kalıcı } \\
\text { Listede } \\
\text { Kültür } \\
\text { Mirası } \\
\text { Olmayanlar }\end{array}$ & $\begin{array}{c}\text { Geçici } \\
\text { Listede } \\
\text { Kültür } \\
\text { Mirası } \\
\text { Olanlar }\end{array}$ & $\begin{array}{c}\text { Geçici } \\
\text { Listede } \\
\text { Kültür } \\
\text { Mirası } \\
\text { Olmayanlar }\end{array}$ \\
\hline Toplam & 16 & 10 & 5 & 21 & 13 & 13 \\
\hline$\%$ & $\% 61,53$ & $\% 38,46$ & $\% 19,23$ & $\% 80,76$ & $\% 50$ & $\% 50$ \\
\hline
\end{tabular}

Tablo 13'e göre Kültür Portalında kayıtlı anıtsal kültür miraslarından sanal turda en fazla oranla yer verilen il sanal turları \%48,38 oranıyla Kırşehir ve \%42,85 oranıla Trabzon Sanal Tur 2'dir. Kırşehir'de Kültür Portalında kayıtlı anıtsal kültür mirası sayısı 31 iken sanal turda 15'ine yer verilmiştir. Trabzon'da Kültür Portalında kayıtlı anıtsal kültür mirası sayısı yedi iken Trabzon Sanal Tur 2'de bunlardan üçü bulunmaktadır. Bu iki ilden sonra \%20'lik oranla Kayseri ve Kırklareli gelmektedir. Kayseri'de Kültür Portalında kayıtlı beş anıtsal kültür mirası bulunurken bunlardan biri sanal turda mevcuttur. Kırklareli'nde ise Kültür Portalında kayıtlı 10 anıtsal kültür mirasının ikisine sanal turda yer verilmektedir. Trabzon Sanal Tur 1, Balıkesir ve Çorum sanal turlarında sırasıyla \%14,28, \%8,24 ve \%6,31'lik oranlarla Kültür Portalında kayıtlı anıtsal kültür mirasları sanal turda verilmiştir. Trabzon Sanal Tur 1'de yedi anıtsal kültür mirasından birine, Balıkesir'de 182 anıtsal kültür mirasından 15'ine ve Çorum'da 95 anitsal kültür mirasından altısına yer verilmiştir. Afyonkarahisar, Elazığ, Kastamonu, Artvin, Ordu ve Denizli illerindeki oranlar \%3'ün altındadır. Sırasiyla illerin oranı \%2,24, \%1,63, \%1,50, \%1,44, \%0,58 ve \%0,13'tür. Kültür Portalında kayıtlı anıtsal kültür mirası Afyonkarahisar'ın 140 iken sanal turda üu̧üne, Elazı '̆' 1222 iken sanal turda ikisine, Kastamonu'nun 113 iken sanal turda 17'sine, Artvin'in 208 iken sanal turda üçüne, Ordu'nun 170 iken sanal turda birine ve Denizli'nin 742 iken sadece birine sanal turda yer verilmiştir. Bayburt, Gaziantep, Gümüşhane ve Karabük illerinin Kültür Portalında kayıtlı anıtsal kültür miraslarının hiçbiri sanal turda bulunmamaktadır (Bkz. Tablo 13).

UNESCO Dünya Mirası Türkiye Kalıc Listesinde kayıtlı mirası ve kent sanal turu bulunan iller Çorum, Denizli, Karabük, Konya ve Şanlıurfa'dır. Her birinde birer kayıtlı miras olan illerden sadece Şanlıurfa kent sanal turunda bu mirasa yani Göbeklitepe'ye yer verilmiştir. UNESCO Dünya Mirası Türkiye Geçici Listesinde kayıtlı mirası ve kent sanal turu olan iller ise Afyonkarahisar, Balıkesir, Bartın, Denizli, Gaziantep, Kahramanmaraş, Kastamonu, Kayseri, Kırşehir, Konya, Mersin, Şanlıurfa ve Trabzon'dur. Mersin'de geçici listede yer alan dört mirasın dördüne, Bartın, Denizli, Kastamonu, Şanlıurfa ve Trabzon illerinde ise birer tane bulunan miraslara sanal turda yer verilmiştir. Afyonkarahisar'da geçici listede kayıtlı iki mirastan \%50 oranla bir adedi, Kayseri' de üç mirastan \%33,33'lük oranla bir adedi ve Konya'da ise beş mirastan $\% 20$ oranla sadece bir adedi kentlere ait sanal turda bulunmaktadır. Balıkesir, Kahramanmaraş ve Kırşehir'e ait geçici listede yer alan birer mirasa ise kent sanal turlarında yer verilmemiştir (Bkz Tablo 13). 
Tablo 13. Kültür Portalındaki Anıtsal Kültür Mirası ve UNESCO Dünya Mirası Listelerindeki Kültür Miraslarının Sanal Turdaki Analizi

\begin{tabular}{|c|c|c|c|c|c|c|c|c|c|c|c|}
\hline \multirow[t]{3}{*}{ İl } & \multicolumn{2}{|c|}{$\begin{array}{l}\text { Bakı Nokta } \\
\text { Sayıs1 }\end{array}$} & \multicolumn{3}{|c|}{$\begin{array}{c}\text { Türkiye Kültür } \\
\text { Portalında Anıtsal } \\
\text { Kültürel Miras }\end{array}$} & \multicolumn{6}{|c|}{$\begin{array}{l}\text { UNESCO Dünya Mirası Türkiye Kalıcı ve } \\
\text { Geçici Listesindeki Kültür Mirası }\end{array}$} \\
\hline & \multirow{2}{*}{$\begin{array}{c}\text { Bak1 } \\
\text { Nokt } \\
\text { a } \\
\text { Sayıs } \\
1\end{array}$} & \multirow{2}{*}{$\begin{array}{c}\text { Uydu } \\
\text { Haritası } \\
\text { Bakı } \\
\text { Noktasında } \\
\text { n } \\
\text { Çıkarılınca }\end{array}$} & \multirow{2}{*}{$\begin{array}{l}\text { Kültür } \\
\text { Portalınd } \\
\text { a Kayitlı }\end{array}$} & \multirow{2}{*}{$\begin{array}{c}\text { Sanal } \\
\text { Turda } \\
\text { Verile } \\
\mathrm{n}\end{array}$} & \multirow[b]{2}{*}{$\%$} & \multicolumn{3}{|c|}{$\begin{array}{c}\text { Kalıcı Listede Yer Alan } \\
\text { Kültür Mirası }\end{array}$} & \multicolumn{3}{|c|}{$\begin{array}{c}\text { Geçici Listede Yer Alan } \\
\text { Kültür Mirası }\end{array}$} \\
\hline & & & & & & $\begin{array}{l}\text { Listed } \\
\text { e Yer } \\
\text { Alan }\end{array}$ & $\begin{array}{l}\text { Sanal } \\
\text { Turda } \\
\text { Verile } \\
\mathrm{n} \\
\end{array}$ & $\%$ & $\begin{array}{l}\text { Listed } \\
\text { e Yer } \\
\text { Alan }\end{array}$ & $\begin{array}{c}\text { Sanal } \\
\text { turda } \\
\text { verile } \\
\mathrm{n}\end{array}$ & $\%$ \\
\hline $\begin{array}{c}\text { Afyonkarahisa } \\
\text { r }\end{array}$ & 41 & 40 & 140 & 3 & $\% 2,24$ & 0 & 0 & - & 2 & 1 & $\% 50$ \\
\hline Artvin & 38 & 37 & 208 & 3 & $\% 1,44$ & 0 & 0 & - & 0 & 0 & - \\
\hline Balıkesir & 284 & 284 & 182 & 15 & $\% 8,24$ & 0 & 0 & - & 1 & 0 & 0 \\
\hline Bartın & 54 & 54 & 0 & - & - & 0 & 0 & - & 1 & 1 & $\% 100$ \\
\hline Batman & 63 & 63 & 0 & - & - & 0 & 0 & - & 0 & 0 & - \\
\hline Bayburt & 55 & 55 & 1 & 0 & 0 & 0 & 0 & - & 0 & 0 & - \\
\hline Çorum & 13 & 13 & 95 & 6 & $\% 6,31$ & 1 & 0 & 0 & 0 & 0 & - \\
\hline Denizli & 32 & 32 & 741 & 1 & $\% 0,13$ & 1 & 0 & 0 & 1 & 1 & $\% 100$ \\
\hline Elazığ & 50 & 50 & 122 & 2 & $\% 1,63$ & 0 & 0 & - & 0 & 0 & 0 \\
\hline Gaziantep & 25 & 25 & 10 & 0 & 0 & 0 & 0 & - & 3 & 0 & 0 \\
\hline Giresun & 36 & 35 & 0 & - & - & 0 & 0 & - & 0 & 0 & - \\
\hline Gümüşhane & 44 & 43 & 2 & 0 & 0 & 0 & 0 & - & 0 & 0 & - \\
\hline $\begin{array}{c}\text { Kahramanmar } \\
\text { aş }\end{array}$ & 27 & 27 & 0 & - & - & 0 & 0 & - & 1 & 0 & 0 \\
\hline Karabük & 53 & 53 & 3 & 0 & 0 & 1 & 0 & 0 & 0 & 0 & - \\
\hline Kastamonu & 114 & 113 & 113 & 17 & $\% 1,50$ & 0 & 0 & - & 1 & 1 & $\% 100$ \\
\hline Kayseri & 19 & 19 & 5 & 1 & $\% 20$ & 0 & 0 & - & 3 & 1 & $\begin{array}{c}\% 33,3 \\
3 \\
\end{array}$ \\
\hline Kirklareli & 67 & 67 & 10 & 2 & $\% 20$ & 0 & 0 & - & 0 & 0 & - \\
\hline Kırşehir & 111 & 111 & 31 & 15 & $\begin{array}{c}\% 48,3 \\
8 \\
\end{array}$ & 0 & 0 & - & 1 & 0 & 0 \\
\hline Konya & 74 & 74 & 0 & - & - & 1 & 0 & 0 & 5 & 1 & $\% 20$ \\
\hline Mersin & 374 & 374 & 0 & - & - & 0 & 0 & - & 4 & 4 & $\% 100$ \\
\hline Ordu & 12 & 11 & 170 & 1 & $\% 0,58$ & 0 & 0 & - & 0 & 0 & - \\
\hline Rize & 47 & 46 & 0 & - & - & 0 & 0 & - & 0 & 0 & - \\
\hline Samsun & 543 & 543 & 0 & - & - & 0 & 0 & - & 0 & 0 & - \\
\hline Şanlıurfa & 82 & 82 & 0 & - & - & 1 & 1 & $\begin{array}{c}\% 10 \\
0 \\
\end{array}$ & 1 & 1 & $\% 100$ \\
\hline $\begin{array}{c}\text { Tekirdağ Sanal } \\
\text { tur } 1\end{array}$ & 31 & 30 & 0 & - & - & 0 & 0 & - & 0 & 0 & - \\
\hline $\begin{array}{c}\text { Tekirdağ Sanal } \\
\text { tur } 2 \\
\end{array}$ & 105 & 105 & & - & - & & 0 & - & & 0 & - \\
\hline $\begin{array}{c}\text { Trabzon Sanal } \\
\text { Tur } 1 \\
\end{array}$ & 74 & 73 & 7 & 1 & $\begin{array}{c}\% 14,2 \\
8 \\
\end{array}$ & 0 & 0 & - & 1 & 1 & $\% 100$ \\
\hline $\begin{array}{c}\text { Trabzon Sanal } \\
\text { Tur } 2 \\
\end{array}$ & 50 & 49 & & 3 & $\begin{array}{c}\% 42,8 \\
5\end{array}$ & & 0 & - & & 1 & $\% 100$ \\
\hline
\end{tabular}

Kentlerin tanıtılmasında bir materyal olarak ortaya çıan kent sanal turlarında kentlere ziyarette önemli bir odak olan kültürel miraslara yer verilmesi yönünde yapılan çalışmada kültürel miraslarının yanı sıra kente dair sanal tura erişim konusunda arama motorlarında kullanılan anahtar kelimeler ve sanal turun genel özellikleri de analiz edilmiştir. Kente dair sanal turlar sonuçlarına en fazla Yandex arama motorunda "kent sanal turu", Google arama motorunda ise "360 tur" anahtar kelimeleriyle ulaşılmıştır. Ulaşılan kent sanal turlarında ana sayfa, ana sayfa arka fonu, logonun veya kurum işletme adının bulunduğu konum, bakı noktaları listesinin ekrandaki konumu, sanal turu sağlayan kamu kurum ve işletme, sanal tur eklentileri ve kent 
sanal turlarındaki bakı sayısı verileri analiz edilerek mevcut kent sanal turlarındaki ağırlıklı olarak uygulama yaklaşımı tespit edilmiştir. Bu tespit sonucunda incelenen turlarda yoğun olarak arka fonda uydu haritası kullanıldığı, bakı listelerine çoğunlukla ana sayfanın sağında, yapan kurum veya işletmeye dair veriye sol üst köşede yer verildiği, genellikle belediyeler tarafından sanal turların oluşturulduğu, bakı sayısının 0-49 arasında yoğunluk gösterdiği anlaşılmaktadır. Bu bilgiler doğrultusunda belli bir kent sanal tur standardı oluşturulma yönünde kullanılacak veri haline getirilmiştir.

Erişilen kent sanal turlarında kültürel mirasa ağırlık verilmediği sanal turlar gibi açık erişimli bir platform sunan Kültür Portalındaki anıtsal yapılar ve kültürel miraslara uluslararası tanınırlık sağlayan UNESCO Dünya Mirası Listelerindeki yer alan miraslara bakılarak tespit edilmiştir.

\section{TARTIŞMA, SONUÇ ve ÖNERILLER}

Sanal turlar pek çok alanda tanıtım aracı olarak kullanılmaktadır. Bu amaçlı kullanım yerlerinden birisi de kentlerdir. Kentlerin doğru ve etkili bir şekilde tanıtılması kente gelen ziyaretçi sayısını arttırmakta ve bu durum kente ve kentte yaşayanlara her anlamda fayda sağlamaktadır. Durmaz ve diğerleri (2018)'in yaptığı çalışmada sanal turların merak duygusu uyandırarak seyahat isteğini arttırabileceği ve sanal tur deneyimi ile beğenilen yerlerin canlı olarak görünmek istenebileceği belirtilmiş ve kişilerin özel hayatlarında bu teknolojiyi kullanarak seyahat planlarını oluşturduğu bilgisine ulaşıldığı ortaya konmuştur. Ziyaret etme isteğine katkı sağlayan sanal turların kent bağlamında da kullanılması ile kentlerin ve kentte yer alan kültürel mirasların tanıtımına katkı sağlanacağı düşünülmekte ve bazı kentlerde bu bağlamda sanal turun kullanmaya başladığı görülmektedir. Çoğunlukla belediyeler tarafından hazırlandığı tespit edilen kent sanal turları diğer kamu kurumlarından olan valilik ve il özel idare ile işletmeler tarafından da hazırlanmaktadır. Kentlerin tanıtımda diğer kurumlara göre daha doğrudan katkı koyması beklenen kurumun belediyeler olduğu düşünüldüğünde çıkan bu sonuç olumludur. Türkiye'deki tüm il belediyelerine bu durum örnek oluşturmalı ve uygulamanın tüm belediyelerce yapılması sağlanmalıdır. Aksoy ve Baş (2020'ın çalışmasında bahsedildiği gibi belediyelerin sanal tur kullanımı şehirlere ilişkin gerçekleştirecekleri tanıtım ve tutundurma çabalarına artı faydalar sağlayacaktır. İnternetten erişim sağlanan bu turlarda yapı, sokak, park vs. gibi kent öğelerine yer verilerek kentte dair tanıtımın yanında bir navigasyon görevi de görmektedir. Kent sanal turları sadece görsel bir materyal olmaktan ziyade yapılan eklentiler ile kent tarihçesi, kente dair yapılan yayınlar, eski-yeni fotoğraflar, kentin çeşitli tarihlerine dair harita veya krokiler, somut ve somut olmayan kültürel miraslar vs. gibi verilerin bulunabileceği bir arşiv haline getirilmelidir. İncelenen sanal turlarda uydu haritası, hava fotoğrafı, müzik, sesli ve yazılı bilgilendirme ve dil seçeneği eklenti olarak karşılaşılanlardır. Sanal turların arka fonlarında çoğunlukla uydu haritasına yer verilmesine karşın hava fotoğrafı ve tarihi yapının da arka fonda yer aldığı sanal turlar mevcuttur. Uydu ve hava fotoğrafı kenti bütün olarak algılamayı sağlaması açısından önemlidir ve bunların her ikisinin de tüm sanal turlarda verilmesi gerekmektedir. Sanal turu sağlayan kurum veya işletmeye ait logo veya bilgi sanal tur ekranın çoğunlukla sol üst köşesinde ve bakı listesi ise yine çoğunlukla sağda yer almaktadır. Bunlar için belli bir düzen oluşturulmalı, bu düzen mevcut ve yapılacak tüm kent sanal turlarında uygulanmalıdır. Böylelikle ülke bağlamında bütüncül bir tanıtım ve bilgi kaynağı elde edilmiş olacaktır. Müzik eklentisi olan sanal turlarda bazı müzikler yöreye özgüdür. Yöreye ait müziklere yer verilmesi kentin somut olmayan mirasını da bu sanal turlarda tanıtması açısından gerekli ve önemlidir. Bu tür yöreye özgü sesli veriler mevcutsa sanal turda aktarılmalıdır. Sesli ve yazılı bilgilendirmesi olan sanal turlarda kentin tarihçesi veya yapıların tarihçesi verilerek sanal tur daha öğretici ve bilgilendirici bir hal almaktadır. Bu sesli ve yazılı bilgilendirmeler sanal turun her aşamasında kullanılmalı ve bu sayede çeşitli engellilerinde erişimi sağlanmalıdır. Sanal turda 
farklı dil seçeneği eklentileri yapılarak sadece Türkçe bilenler değil farklı dil kullanıcılarının da sanal turu ziyaret edeceği öngörülmelidir. Bu eklentiler incelenen sanal turlarda kısmen yer almaktadır. Bunların sayısının arttırılması ve daha nitelikli hale getirilerek tüm kent sanal turlarında yer alması kentin tüm yönüyle ziyaretçiye ulaşmasını sağlayacaktır. Bu durum Sürme ve Atılgan (2019)'ın sanal ortamın kullanılabilirliği arttıkça sanal tur memnuniyetinin de arttığ sonucuna ve benzer bir durumu güven bağlamında değerlendiren Aksoy ve Baş (2020)'ın kullanıcıların güven duydukları ve kullanımını kolay buldukları sanal turu faydalı olarak görme eğilimi içinde olmaları sonucuna paralellik göstermektedir.

Kentlerin tanıtımı için önemli unsurlardan birisi olan kültür miraslarının kent tanıtımı için oluşturulan sanal turlarda yer alması kentin tanınması, algılanması ve ziyaret etme isteği oluşturması açısından önem kazanmaktadır. Özellikle UNESCO Dünya Mirası Listelerindeki Türkiye'ye ait miraslara bu sanal turlarda yer vermek uluslararası tanınırlığı kente mal etme açısından önemlidir. Balıkesir kent sanal turu 284 ile en fazla bakı noktasına sahip kent sanal turu olmasına rağmen Kültür Portalında kayıtlı 182 anitsal kültür mirasından sadece 15'ine yer verilmiş ve UNESCO Geçici Listesinde yer alan bir adet kültür mirasına ise yer verilmemiştir. Kırşehir \%48,38 ile en fazla oranla Kültür Portalında kayıtlı anıtsal kültür mirasına sanal turda yer veren kent olmasına rağmen geçici listede yer alan bir adet kültür mirasına yer vermemiştir. Bunların aksine Mersin ve Şanlıurfa UNESCO listelerinde yer alan tüm kültür miraslarına sanal turlarında yer vermiştir. Mersin iline ait sanal tur en fazla bakı noktasına sahip Samsun kent sanal turundan sonra 374 bakı noktası ile ikincidir. Mersin'e ait Kültür Portalında kayıtlı anıtsal kültür mirası görünmemektedir. Pek çok kültür mirasa sahip olan Mersin'in Kültür Portalında kaydının eksik olduğu görülmektedir. UNESCO geçici listesinde yer alan dört adet kültür mirasının hepsine Mersin kent sanal turunda yer verilmiştir. Şanlıurfa'nın da Kültür Portalında kayıtlı anıtsal kültür mirası görünmemektedir. Bakı nokta sayısı 82 ile çok fazla olmamasına rağmen UNESCO hem kalıcı hem de geçici listesinde yer alan birer adet kültür mirasına sanal turda yer vermiştir. Toplumun tarihi değerlerinin korunması ve sürdürülebilir olması için olanak sağlamamakta, aynı zamanda bu kültürel yapıtların sanal tur için yeniden deneyimlenmesi ve kültür turizmi için yeni bir olanağın, deneyimleme alanının yaratılması açısından önemlidir (Guliyeva ve Guliyev, 2020: 32).

Kentlerin tanıtım araçlarından biri haline gelen sanal turlarda kentlere ait önemli bilgiler veren kültür miraslarına da yer verilmelidir. Bilgiye anında erişim günümüz yaşantısında önem arz etmektedir. Bu nedenle bu tarz sanal turlar bilgiye erişimi en hizlı ve en ucuz şekilde sağlamaktadır. Kentin tüm kültürel miras birikimi sanal turlara doğru bilgilerle, yapıyı algılayıcı ve öğretici şekilde aktarılmalıdır. Tüm kullanıcıların bu bilgilere erişimini sağlamaya yönelik gerekli bütün eklentiler evrensel bir yöntem ile sağlanmalıdır.

\section{KAYNAKÇA}

Aksoy, G. ve Baş, M. (2020). Dijital Turizm Kapsamında Şehir Tanıtımında Kullanılan Bir Araç Olarak Sanal Tur. Türk Turizm Araştırmaları Dergisi, 4(3), 2542-2564. doi:10.26677/TR1010.2020.

Altınbay, R. (2019). Sosyal Bilgiler Dersinde Sanal Tur Kullanımının Sosyal Bilgiler Öğretmenlerinin Görüşlerine Göre Değerlendirilmesi. Yüksek Lisans Tezi, Dokuz Eylül Üniversitesi, İzmir.

Arat, T. ve Baltacioğlu, S. (2016). Sanal Gerçeklik ve Turizm. Selçuk Üniversitesi Sosyal Bilimler Meslek Yüksek Okulu Dergisi, 19(1), 103-118.

Daşdemir, İ. (2019). Sosyal Bilgiler Öğretiminde Sanal Tur Uygulamalarının Etkisinin İncelenmesi. Doktora Tezi, Afyon Kocatepe Üniversitesi, Afyonkarahisar. 
Derman, E. (2012). 360 Derece Panoramik Sanal Tur Uygulaması: Dumlupınar Üniversitesi Örneği. Yüksek Lisans Tezi, Dumlupınar Üniversitesi, Kütahya.

Durmaz, C., Bulut, Y. ve Tankuş, E. (2018). Sanal GerçekliğïnTurïzme Entegrasyonu: Samsun'daki 5 Yıldizlı Otellerde Uygulama. Turkish Journal of Marketing, 3(1), 32-49. doi:10.30685/tujom.v3i1.27

G1lıç, İ. I. (2020). Sanal Müze Destekli İşbirlikli İngilizce Öğrenme Etkinliklerinin Ortaokul 7. Sınıf Öğrencilerinin Okuduğunu Anlama Başarılarına ve Sanal Müze Memnuniyetlerine Etkisi. Yüksek Lisans Tezi, Mersin Üniversitesi, Mersin.

Guliyeva, D. ve Guliyev, Z. (2020). Kültürel Yapıtların Sanal Rekonstrüksiyon Sonrası Turizm ve Kültürel Bellek Bağlamında Virtal Karabağ Sitesi Sanal Tur Videolarının Analizi. Uluslararası Turizm, İşletme, Ekonomi Dergisi, 4(2), 20-33.

Halaç, H. H. ve Saatci, B. (2018). Tarihi Yapılardakï Kent Müzelerïnïn Sanal Tur Yöntemi ile Tanitılması: Bursa Kent Müzesi. The Journal of Academic Social Science Studies, (72), 349-365.

http://2aajans.com/sanaltur/batman/ > [Erişim Tarihi:16.04.2020]

http://360.karabuk.bel.tr/ >[Erişim Tarihi: 2.04.2020]

https://balikesir.bel.tr/360/index.html >[Erişim Tarihi: 2.04.2020]

https://cbs.kayseri.bel.tr/panoroma.html?p=360meydan\&v=04 >[Erişim Tarihi: 2.04.2020]

http://corum.gov.tr/ortak_icerik/corum/sanaltur/index.html >[Erişim Tarihi: 2.04.2020]

https://gaziantep.bel.tr/sanal/index.html >[Erişim Tarihi: 2.04.2020]

http://kahramanmaras.bel.tr/3d-sanal-tur >[Erişim Tarihi: 2.04.2020]

https://konya.bel.tr/360/ >[Erişim Tarihi: 2.04.2020]

https://sanalgezinti.com/yeni/kirklareli-valiligi/index.html >[Erişim Tarihi: 2.04.2020]

https://vr.mersin.bel.tr/\#!/Ulu-Cami-31b/?dil=Tr\&ath=176\&atv=-39\&fov=8[Erişim

Tarihi: 2.04.2020]

https://www2.denizli.bel.tr/sanaltur/ >[Erişim Tarihi: 2.04.2020]

http://www.afyon.bel.tr/modul/sanaltur/ > [Erişim Tarihi: 16.04.2020]

http://www.bartinsanaltur.com/ >[Erişim Tarihi: 2.04.2020]

http://www.bayburt.bel.tr/webfiles/360/index.html >[Erişim Tarihi: 2.04.2020]

http://www.co2medya.com/kta/artvin/turistik/tur/artvin.html > [Erişim Tarihi:16.04.2020]

http://www.co2medya.com/kta/giresun/turistik/tur/giresun.html >[Erişim Tarihi: 2.04.2020]

http://www.co2medya.com/kta/gumushane/turistik/tur/gumushane.html >[Erişim Tarihi: 17.04.2020]

http://www.co2medya.com/kta/rize/turistik/tur/rize.html >[Erişim Tarihi: 2.04.2020]

http://www.co2medya.com/kta/trabzon/turistik/tur/trabzon.html >[Erişim Tarihi: 2.04.2020]

http://www.co2medya.com/ordu/ >[Erişim Tarihi: 2.04.2020]

http://www.co2medya.com/projeler/kirsehir/ >[Erişim Tarihi: 2.04.2020]

https://www.elazig.bel.tr/sanal360/ >[Erişim Tarihi: 2.04.2020] 
https://www.kastamonu.bel.tr/sanaltur/index.html >[Erişim Tarihi: 2.04.2020]

https://www.kulturportali.gov.tr/>[Erişim Tarihi: 17.04.2020]

http://www.panoraturk.com/360/tekirdag/index.htm >[Erişim Tarihi: 2.04.2020]

http://www.samsunsanaltur.com/ >[Erişim Tarihi: 2.04.2020]

http://www.sanliurfa.gov.tr/ortak_icerik/sanliurfa/kuresel/index.html >[Erişim Tarihi: 2.04.2020]

http://www.trabzon360.com/>[Erişim Tarihi: 2.04.2020]

http://www.trakya360.com/ >[Erişim Tarihi: 2.04.2020]

http://www.unesco.org.tr/Pages/125/122/UNESCO-D\%C3\%BCnya-Miras\%C4\%B1-Listesi $>$ [Erişim Tarihi: 17.04.2020]

Koca, N. ve Daşdemir, İ. (2018). Sosyal Bilgiler Öğretiminde Sanal Tur Uygulamaları. Journal of Turkish Studies, 13(27), 1007-1016. doi:10.7827/turkishstudies.14420

Oruç, M. C., Yıldırım, İ. M., İmamoğlu, Ö., Demiroğlu, G. ve Mehmet Burak B, L. (2017). Sanal Gerçeklik Uygulamalarının Müzelere Yansımaları: Ayasofya ve Louvre Müzelerinin Karşılaştırmalı Bir Analizi. 1st Eurasian Conference on Language and Social Sciences Proceedings Book içinde (ss. 102-108).

Özer, A. (2016). Sanal Müzede Öğrenmenin Bağlamsal Modelinin Kullanımının Öğrencilerin Akademik Başarısı, Motivasyonu ve Memnuniyet Düzeylerine Etkisi. Doktora Tezi, Ankara Üniversitesi, Ankara.

Sungur, T. ve Bülbül, H. (2019). Sınıf Öğretmeni Adaylarının Sanal Tur Ugulamalarına Yönelik Görüşleri. Bolu Abant İzzet Baysal Üniversitesi Eğitim Fakültesi Dergisi, 19(2), 652-666.

Sürme, M. ve Atılgan, E. (2019). Sanal Müzede Sanal Tur Yapan Bireylerin Memnuniyet Düzeylerini Belirlemeye Yönelik Bir Araştırma. Türk Turizm Araştırmaları Dergisi, 3(4), 1794-1805. doi:10.26677/TR1010.2019

Taşkıran, Ö. ve Kızılırmak, İ. (2019). Deneyimsel Pazarlama Kapsaında Sanal Turların Müze Zïyaretlerïne Etkïsï : Panorama 1453 Örneğii. Uygulamalı Sosyal Bilimler Dergisi, 3(1), 1-19.

Tay, V. (2020). Panorama Tabanlı Sanal Gerçekliğe Göre Tasarlanan Sanal Kampüs Tur Uygulamasının Etkililiğinin Değerlendirilmesi. Yüksek Lisans Tezi, Ankara Üniversitesi, Ankara.

Toprak, İ. H. (2019). Görsel İletişim Tasarımı - Tanıtım ve Turizm Bağlamında 360 Derece Sanal Gezinti Uygulaması: Harput Örneği. Yüksek Lisans Tezi,Firat Üniveristesi, Elazığ. 